\author{
ENFOCAMENT DE RESILIÈNCIA COMUNITÀRIA \\ PER AFRONTAR CONTEXTOS D'EXCLUSIÓ SOCIAL \\ ENFOQUE DE LA RESILIENCIA COMUNITARIA \\ PARA AFRONTAR CONTEXTOS DE EXCLUSIÓN SOCIAL \\ TO APPROACH THE RELATING TO THE COMMUNITY \\ RESILIENCE TO FACE UP SOCIAL EXCLUSION ENVIROMENTS
}

Roger Navarro Domenichelli*

Doi: 10.7203/anuari.psicologia.16.1.57

\begin{abstract}
Resum
La pobresa i la marginació han evolucionat al llarg del temps, presentant-se avui a Europa, com un fenomen complex, multi dimensional i dinàmic, que engloba no només manques econòmiques, sinó també dificultats per a la inserció laboral, la participació social i ciutadana, l'ús de recursos institucionals, l'accés a béns bàsics com l'educació, l'habitatge, la salut o la cultura. La inclusió social, per la seva banda per a la Unió Europea, és «un procés que garanteix que les persones en perill de pobresa i d'exclusió social obtenen les possibilitats i els recursos necessaris per participar plenament en la vida econòmica, social i cultural, i que gaudeixen d'un nivell de vida i de benestar considerat com a normal per a la societat en la qual viu». Cóm enfronten les persones i les llars aquestes desigualtats? Cóm viuen el seu quotidianitat i quins recursos tenen per fer-ho? Un d'aquests recursos és presumiblement la capacitat d'adaptació i superació de les adversitats anomenada «resiliència», analitzada des de les capacitats de les persones, famílies i comunitats per enfrontar i superar les condicions deficitàries, a través de la implementació de diferents estratègies, on s'articulen recursos propis i del seu entorn, en un procés d'acompanyament en els situacions d'inclusió social. El concepte de «resiliència» comunitària ha estat aplicat en múltiples situacions socials -terratrèmols, inundacions, ciclons, fams, violència armada, guerres civils, repressions, etc.-, les quals s'evidencien quan les comunitats s'apropien d'es-
\end{abstract}

* Professor Associat del Departament de Psicologia Social, Facultat de Psicologia. Universitat de València-EG. Avgda. Blasco Ibàñez, 21, 46010 València. Correspondència: $<$ Rogelio.Navarro@uv.es>. 
tratègies de supervivència, esquemes d'organització, compromís, vinculació i altres experiències, per establir nous llaços socials i laborals, adaptar-se i continuar la vida. La «resiliència» és una capacitat que pot ser fomentada durant tot el cicle vital i en totes les persones, famílies i comunitats. La «resiliència» podria, per tant, ser una eina vàlida per enfrontar situacions de desavantatge, adverses, difícils, però perquè aquesta capacitat pot desenvolupar-se, darrere d'una alta qualitat de vida és precisa la provisió d'una estructura d'oportunitats des de les polítiques públiques de Benestar Social.

Paraules clau: exclusió social, processos d'inclusió social, resiliència, capital social.

\section{Resumen}

La pobreza y la marginación han evolucionado a lo largo del tiempo, presentándose hoy en Europa, como un fenómeno complejo, multidimensional y dinámico, que engloba no solamente carencias económicas, sino dificultades para la inserción laboral, la participación social y ciudadana, el uso de los recursos institucionales y el acceso a bienes básicos como la educación, la vivienda, la salud o la cultura. La inclusión social, por su parte y para la Unión Europea, se define como «un proceso que garantiza que las personas amenazadas de pobreza y exclusión social, pueden acceder a los recursos necesarios para participar, plenamente, en la vida económica, social y cultural, y que gozan de un nivel de vida y de bienestar, considerados como normales para la sociedad en que vivimos». Pero ¿cómo afrontan, aquellas personas y sus hogares tales desigualdades? ¿Cómo viven su cotidianidad y qué recursos tienen para ello? Uno de estos recursos es, presumiblemente la capacidad de adaptación y superación de las adversidades llamada «resiliencia», analizada desde las capacidades de las personas, familias y comunidades para afrontar y superar leas condiciones deficitarias a través de la implementación de diferentes estrategias, donde se articulan recursos propios y del entorno, en un proceso de acompañamiento en los episodios de inclusión social. El concepto de «resiliencia» comunitaria ha sido aplicado en múltiples situaciones sociales -terremotos, inundaciones, ciclones, situaciones de hambrunas, violencia armada, guerras civiles, represiones, etc.-, que se evidencian cuando las comunidades se apropian de estrategias de supervivencia, esquemas de organización, compromiso, vinculación, y otras experiencias para establecer nuevos lazos sociales y laborales, adaptarse y seguir viviendo. Así la «resiliencia» aparece como una capacidad que puede ser fomentada durante todo el ciclo vital y en todas las personas, familias y colectivos. La «resiliencia» podría, por tanto, ser una herramienta válida para afrontar situaciones de desventaja, adversas, difíciles. Pero para que pueda desenvolverse, detrás de una alta calidad de vida, se precisa la provisión de una estructura de oportunidades desde las políticas públicas de Bienestar Social.

Palabras clave: exclusión social, procesos de inclusión social, resiliencia, capital social. 


\begin{abstract}
Poverty and marginalization have evolved over time, appearing today in Europe, as a complex, multidimensional and dynamic phenomenon, which encompasses not only economic deprivation but also difficulties in the labor market, social and citizen participation, the use institutional resources, access to basic goods such as education, housing, health and culture. Social inclusion, meanwhile for the European Union, is «a process which ensures that those at risk of poverty and social exclusion gain the opportunities and resources necessary to participate fully in economic, social and cultural life, and enjoy a standard of living and welfare considered normal for the society in which he lives». How do people cope with these inequalities and households? How do they live their daily lives and what resources they have to do? One of these resources is presumably adaptability and overcoming adversity called resilience, analyzed from the capacities of individuals, families and communities to meet and overcome the deficit conditions through the implementation of different strategies, where equity is articulated and their environment, in a process in accompaniment in the processes of social inclusion. The concept of community «resilience» It has been applied in many social situations -earthquakes, floods, cyclones, famine, armed violence, civil wars, repression, etc.-, which are evident when communities hijack survival strategies, schemes organizational commitment, attachment, and other experiences to establish new social and labor ties, adapt and continue life. «Resilience» is an ability that can be fostered throughout the life cycle and in all individuals, families and communities. "Resilience» could therefore be a valid address disadvantage, adverse, difficult tool, but this capacity can be developed in pursuit of a high quality of life is the provision of a precise structure of opportunities from public policy of Social Welfare.
\end{abstract}

Key words: social exclusion, social inclusion processes, resilience, social capital.

\title{
Vulnerabilitat social
}

La vulnerabilitat és un problema emergent que sorgeix repetidament en el debat sobre polítiques públiques adreçades a reduir la pobresa, a promoure la mobilitat social i a garantir l'exercici de la ciutadania. En l'ús actual, la vulnerabilitat denota risc, fragilitat, impotència o danys; Aquestes condicions d'identificació són benvingudes al diccionari de la Reial Acadèmia de la llengua espanyola i diu que és «la probabilitat de ser danyat o ferit». Mentre que tals significats són vàlids, no inclouen la possibilitat de controlar els efectes de la materialització del risc, condició que necessàriament ha de ser present en l'estudi de vulnerabilitat social, atès que això inclou tant l'exposició a un risc1 i la mesura de la capacitat de cada unitat de referència per a afrontar-lo, ja sigui a 
través d'una resposta endògena o gràcies a un suport extern, però simple acceptació del risc és una manera passiva per adaptar-se i és equivalent a resignació, que emana del fatalisme; una adaptació és activa, d'altra banda, és una forma particular de resposta, el caràcter durador del qual implica reestructuracions internes -de vegades profundes- de les unitats de referència.

Per incloure aquesta especificació, en la incapacitat de respondre es distingueix entre la ineptitud per fer front a riscos i la incapacitat per adaptar-se activament a les seves conseqüències, elements que corresponen al que Moser (1998) denomina sensitivity i resilience, respectivament:

La noció de vulnerabilitat no es limita només a l'àmbit de la pobresa, camp d'aplicació: «la idea més general de vulnerabilitat -per simplificar l'exposició ens referirem només a llars- es refereix a un estat de les llars, que varia inversament relacionada amb la capacitat per controlar les forces que configuren el seu propi destí, o per contrarrestar els seus efectes sobre el benestar» (Kaztman, 2000).

Vulnerabilitat social es refereix a manca de béns o la seva obsolescència. L'actiu ha de ser útil per al desenvolupament d'estratègies de mobilitat social i no només a sortir de la pobresa o fer front a les crisis econòmiques, però la vulnerabilitat no només és defineix segons actius disponibles sinó segons la seva relació amb el context soci-econòmic, representada per les estructures d'oportunitats, que son «probabilitats d'accedir als béns, serveis o activitats que afecten el benestar de l'habitatge perquè proporcionar a l'ús de recursos propis o proporcionar recursos nous, útils per a la mobilitat i la integració social, a través dels canals existents» (Kaztman, 2000). Per tant, les condicions de vulnerabilitat es refereixen tant la disponibilitat d'actius com a les possibilitats d'accés ofertes per l'estat, el mercat i la comunitat, però també cal tenir una estratègia a fer un ús raonable d'ells i de les oportunitats estructurals, afavorint el seu desplegament.

Per tant, la vulnerabilitat social pot ser entesa com la combinació de: i) esdeveniments, processos o trets que són l'adversitat potencial per a l'exercici de diferents tipus de drets ciutadans o l'assoliment dels projectes de comunitats, habitatges i individus; ii) incapacitat per respondre a la materialització d'aquests riscos; i (iii) incapacitat per adaptar-se a les conseqüències de la materialització dels mateixos.

\section{Exclusió social i inclusió social}

La pobresa i la marginació han evolucionat al llarg del temps i es presenten, avui, com un fenomen complex, multi dimensional i dinàmic que engloba no només manques econòmiques, sinó també dificultats per a la inserció laboral, la participació social i ciutadana, l'ús de recursos institucionals, l'accés a béns 
bàsics com l'educació, l'habitatge, la salut o la cultura. En definitiva, l'exclusió social es refereix a una condició de «alienitat» i una ruptura del vincle social de determinats grups de població, i/o de persones individuals, que queden en condicions de vida precàries, sense accés a recursos de tot tipus i amb escasses possibilitats d'una ràpida sortida a aquesta condició.

Encara sent un concepte variable i dinàmic, es pot sintetitzar que el fenomen de l'exclusió social es tradueix en un procés mitjançant el qual els individus o grups són total o parcialment exclosos d'una participació plena en la societat en la qual viuen i que indubtablement, atempta contra la integració social traslladada als plànols econòmic, social i polític.

Una persona vulnerable és aquella l'entorn personal de la qual, familiar-relacional, soci-econòmic o polític-administratiu pateix alguna feblesa i, en conseqüència, es troba en una situació de risc que podria desencadenar un procés de l'exclusió social. El nivell de risc serà major o menor depenent del grau de deteriorament de l'entorn.

En ser així, l'exclusió social ha d'assumir-se com una problemàtica europea que concerneix a tots els estats membres i les seves regions, la xarxa de les quals de causalitat i d'intervenció ha de comptar amb mecanismes de cooperació entre estats i diversos agents socials i econòmics.

En definitiva, apareix així de forma clara la meta consistent en l'assoliment d'un nivell suficient de benestar de tots els ciutadans i ciutadanes, que vinguen a garantir les condicions mínimes necessàries per a l'existència d'una igualtat en el seu sentit material, més enllà de les meres declaracions formals de drets. Aquest nivell de benestar ha de ser la síntesi de diversos factors conjugats: treball, habitatge digne, rendes familiars i protecció social, entre altres.

Per la seva banda la inclusió social és un procés que assegura a les persones un augment de les oportunitats i els recursos necessaris per participar plenament en la vida econòmica, social i política; permetent-los gaudir d'unes condicions de vida normals. Així mateix, ofereix la possibilitat de participació igualitària en la societat de tots els seus membres i en les seves múltiples dimensions socials -econòmica, legal, política, cultural...-

La inclusió activa és un concepte utilitzat per la Unió Europea, en el marc de l'estratègia europea per a la protecció i la inclusió social. Aquest terme descriu un enfocament global de la promoció de la integració de les persones més desfavorides, a través del desenvolupament d'una estratègia integrada composta de tres pilars:

- mercats de treball que afavoreixin la inserció.

- un complement de recursos adequat.

- l'accés a serveis de qualitat. 


\section{La resiliència: acostament conceptual}

El paradigma de la resiliència implica una perspectiva innovadora que va sorgir primer en les ciències físiques i després s'ha incorporat en les ciències humanes, emergint amb inusitada rapidesa des de diversos camps. El paradigma de la resiliència té actualment un suport teòric i pragmàtic que permet considerar-ho com un instrument útil en les intervencions socials. El concepte de resiliència, prové de la física dels materials i es refereix a la capacitat dels mateixos de recuperar la seva forma inicial després d'haver estat sotmès pressió.

Des de fa alguns anys ha començat a manejar-se el concepte de resiliència com aquella qualitat de les persones per resistir i refer-se davant situacions traumàtiques o de pèrdua. En l'esfera de les ciències socials la incorporació de la noció de resiliència es va començar a expressar especialment des de la Psicologia; principalment per referir-se a les respostes «positives» dels individus que es van enfrontar davant un esdeveniment pertorbador o advers.

La resiliència és entesa com un concepte que explica la forma en què les persones enfronten situacions violentes o amenaçadores durant la seva vida, sent més que la resistència mateixa i molt més àmplia que l'adaptabilitat, que només és un dels seus elements (Manciaux, 2003). De fet, no existeix un concepte universalment acceptat per definir-la, però gairebé tots els autors intenten explicar-la com un procés, una capacitat, un creixement, un enfrontament positiu o una habilitat (González-Arratia, 2007).

El concepte de resiliència ha estat desenvolupat principalment des de dos enfocaments diferents, i ha adoptat matisos diferents en cadascun d'ells. Així, el concepte que manegen els investigadors francesos relaciona la resiliència amb el concepte de creixement posttraumàtic, en entendre la resiliència com la capacitat no només de sortir indemne d'una experiència adversa sinó d'aprendre d'ella i millorar. Per a alguns autors, la resiliència s'ha definit com la capacitat d'una persona o grup per seguir projectant-se en el futur, malgrat esdeveniments desestabilitzadors, de condicions de vida difícils i de traumes de vegades greus (Manciaux i al., 2001). Una altra definició de resiliència segons Edith Grotberg (1997) és «la capacitat de l'ésser humà per fer front a les adversitats de la vida, superar-les i ser transformat positivament per elles».

No obstant això, el concepte de resiliència manejat pels autors nord-americans és més restringit, $\mathrm{i}$ fa referència exclusivament al procés d'afrontament que ajuda a la persona enfrontada a un succés advers a mantenir-se intacta, diferenciant-ho del concepte de creixement posttraumàtic. Així, des del corrent nord-americà se suggereix que el terme resiliència sigui reservat per denotar la tornada homeostàtica del subjecte a la seva condició anterior, mentre que s'utilitzin termes com thriving o creixement posttraumàtic, per fer referència a l'obtenció de benefici o el canvi a millor, després de l'experiència traumàtica (Carver, 1998, O'Leary, 1998). 
D'altra banda, segons Vanistendael (1994): «la resiliència distingeix dos components: la resistència enfront de la destrucció, és a dir, la capacitat de protegir la pròpia integritat, sota pressió i, d'altra banda, mes allà de la resistència, la capacitat de forjar un comportament vital positiu malgrat les circumstàncies difícils». Per a Luthar (2000) la resiliència «és un procés dinàmic que té per resultat l'adaptació positiva en contextos de gran adversitat». Per Cyrulnik, (2002) el terme fa referència a un procés o a un esdevenir, de manera que no és tant la persona la que és resilient, sinó la seva evolució i el procés d'organització de la seva pròpia història vital. Llavors, la resiliència no ha de considerar-se com una capacitat estàtica, ja que varia a través del temps i de les circumstàncies. En altres paraules, és el resultat de l'equilibri entre factors de risc, factors protectors i la pròpia personalitat de l'ésser humà.

De «ser resilient» es passa a «estar resilient» i actualment es considera que «s'aprèn» a ser resilient. La seva aplicació programàtica ha tingut una expansió considerable, des dels programes inicials focalitzats en la infància i adolescència als més recents que es concentren en famílies i adults majors, així com en institucions i comunitats. El concepte inicial ha evolucionat a Amèrica Llatina, al de resiliència comunitària, que descriu aquesta condició col-lectiva per travessar, superar crisi, catàstrofes naturals massives d'adversitats superar-les i construir sobre elles.

\section{Resiliència i exclusió social}

La recerca sobre la resiliència en el marc de la pobresa s'ha enfocat bàsicament en tres nivells de factors protectors: els trets i disposicions individuals, la família i la comunitat. En la pobresa existeixen condicions deficitàries de l'ambient que podrien considerar-se una amenaça per a les poblacions que la sofreixen. No obstant això, això dependrà del nivell de vulnerabilitat de les mateixes, ja que davant una amenaça es dinamitzen elements interns de les persones o grups per respondre a elles (Seccombe, 2002). Blaikie, Cannon, David $\&$ Wisner (1996) expressen que la vulnerabilitat d'una població depèn de tres elements: a) L'exposició: que al-ludeix a la susceptibilitat de ser afectat per estar a l'àrea d'influència dels fenòmens perillosos i per la fragilitat física davant els mateixos; b) La fragilitat social: que es refereix a la predisposició de la població de ser afectada com a resultat del nivell de marginalitat o segregació social i les seves condicions de desavantatge o feblesa relativa; i c) La insuficiència de resiliència entesa com la limitació dels individus, per a l'accés i mobilitat de recursos personals, la immobilitat de resposta i les deficiències per absorbir l'impacte de l'adversitat. 
No obstant això, diversos estudis han demostrat que hi ha persones que manifesten una capacitat d'adaptació i superació, hagut de molt probablement al fet que, dels tres components de la vulnerabilitat -exposició, fragilitat social i insuficiència de resiliència-, la resiliència es troba enfortida (Gauto, 2008).

Per tant, que la persona sigui o no resilient, enfront d'una determinada situació, depèn dels recursos actius disponibles en un determinat moment $\mathrm{i}$ territori, i de les estratègies que aquesta efectuï per enfrontar i superar les circumstàncies de la seva adversitat. En determinats moments, disposarà només d'alguns recursos i és probable que les estratègies que empri per combinar-los siguin diferents a cada moment i davant cada situació particular. Per això és important identificar les situacions de vida particulars i els recursos actius disponibles, és a dir, és necessari contemplar una anàlisi micro - de les persones i de les seves llars-i una anàlisi macro -de l'entorn institucional i socioeconòmica- i considerar aquesta relació (Gauto, 2008).

La resiliència se sustenta en la interacció existent entre la persona i l'entorn. Específicament en el plànol de les intervencions psicosocials, el model de resiliència ha canviat la naturalesa dels marcs conceptuals, les metes, les estratègies i les avaluacions. A l'àrea de les metes d'intervenció, aquestes inclouen la promoció d'apropiació positiva al mateix temps que prevenen problemes específics o símptomes. Les estratègies busquen promoure avantatges $\mathrm{i}$ aspectes positius de l'ecologia de l'individu, a més de reduir el risc i promoure processos de desenvolupament humà. L'enfocament de la resiliència entén el desenvolupament humà dins d'un context específic. És a dir, si cada individu està immers en un marc ecològic, llavors per comprendre millor el procés de resiliència, és necessari considerar l'ambient i la cultura de l'individu, igual que les tasques específiques corresponents a cada etapa del desenvolupament. Si es considera l'ecologia de l'ésser humà com a font de recursos i possibilitats per a un desenvolupament sa, llavors la promoció de resiliència passa a ser una responsabilitat compartida entre professionals de diferents disciplines i diferents nivells d'influència.

La resiliència no és absoluta ni s'adquireix una vegada per sempre, és una capacitat que resulta d'un procés dinàmic $\mathrm{i}$ evolutiu que varia segons les circumstàncies, la naturalesa del trauma, el context i l'etapa de la vida i que pot expressar-se de molt diferents maneres en diferents cultures (Manciaux i al., 2001). Com el concepte de personalitat resistent, la resiliència és fruit de la interacció entre el mateix individu i el seu entorn. Parlar de resiliència en termes individuals constitueix un error fonamental. No s'és més o menys resilient, com si es posseís un catàleg de qualitats. La resiliència és un procés, un esdevenir, de manera que no és tant la persona la que és resilient com la seva evolució i el seu procés de vertebració de la seva pròpia història vital (Cyrulnik, 2001). 


\section{L'enfocament de resiliència per afrontar els contextos de risc d'exclusió social}

D'acord amb Michel Manciaux, Stefan Vanistendael, Jacques Lecomte i Boris Cyrulnik (2003): «La resiliència és la capacitat d'una persona o d'un grup per desenvolupar-se bé, per seguir projectant-se en el futur malgrat esdeveniments desestabilitzadors, de condicions de vida difícils i de traumes de vegades greus».

D'aquesta manera, resiliència, és un concepte que s'analitza des de les capacitats de les persones, famílies i comunitats per enfrontar i superar les condicions deficients del seu hàbitat a través de la implementació de diferents estratègies (Kaztman, 1999), on s'articulen recursos propis i del seu entorn. Capacitat que es desenvolupa i construeix durant tota la vida de les persones i molt especialment en contacte amb un entronitzo afavoridor del desenvolupament d'habilitats i capacitats i contenidor, que brinda oportunitats.

Per la Federación Internacional de la Cruz Roja, en el seu document: El camino hacia la resiliencia: Tender puentes entre el socorro y el desarrollo para un futuro más sostenible (2012) la paraula «capacitat» és clau per entendre la resiliència, doncs es tracta d'aquella capacitat basada en diferents avantatges humans, psicològiques, socials, financeres, físiques, naturals o polítiques. En l'enfocament de resiliència es reconeix que sempre hi ha capacitat en persones i comunitats. L'objectiu d'enfortir la resiliència és augmentar aquesta capacitat de resistir a l'efecte de l'adversitat. Es pot considerar que la resiliència siga la capacitat d'una persona, una comunitat, una organització o un país. Un enfocament integral de la mateixa requereix comprendre la interconnexió que existeix entre tots aquests nivells.

D'acord amb els estudis de resiliència, en tots els processos d'enfrontament $i$ superació de les adversitats analitzats, es va identificar la presència de factors interns i factors externs a les persones.

Els primers, es refereixen a factors que estan presents i depenen de cadascun dels subjectes. Es refereixen a característiques personals que afavoreixen l'afrontament d'una situació difícil; ells són: introspecció, independència, capacitat de relacionar-se, iniciativa, creativitat, humor i moralitat. (Wolin i Wolin, 1999), laboriositat (Grotberg, 1977) i autoestima consistent. (Melillo i altres, 2004). Seligman i cols. identifiquen set factors intrapersonals que semblen augmentar la resiliència: regulació de l'emoció, control dels impulsos, anàlisis de les causes, optimisme realista, autoeficàcia, empatia, connexió amb altres persones.

Per la seva banda, Rojas Marcos (2014) considera que els pilars de la resiliència humana els formen diversos atributs protectors: les connexions afectives i tendència a narrar i compartir amb uns altres les experiències difícils; les funcions executives o la capacitat d'introspecció i l'aptitud per obtenir bona 
informació i prendre decisions; la inclinació a localitzar el centre de control dins d'un mateix; una autoestima saludable; la diversificació de les parcel·les de satisfacció; i el pensament positiu, incloent el sentit de l'humor i la capacitat per passar pàgina.

Els segons, es refereixen a aquells factors externs als subjectes, que formen part del seu entorn i exerceixen influència sobre ell. Aquests factors externs sovint són: la família, les amistats, els veïns, la comunitat, la societat. Tots ells, formen part de l'entorn de cada ésser humà i influeixen de manera significativa en ell i de forma positiva i/o negativa, igual que ell influeix sobre ells.

D'acord amb aquest plantejament, tant els factors interns com a externs a lloes persones, podrien considerar-se recursos dels quals disposen les persones $\mathrm{i}$ famílies per fer front a qualsevol risc per a la salut en el seu hàbitat. Per definir recursos, es parteix de la definició donada per Rubén Kaztman i Carlos Filgueira, els qui els defineixen com, «tots els béns que controla una llar tangibles i intangibles» (Kaztman, 1999). Aquests recursos, adquireixen rellevància quan permeten l'aprofitament de les estructures d'oportunitats existents en un determinat moment. En tal cas, l'autor els denomina indistintament actius o capital.

Seguint amb la proposta de Kaztman (1999) es classifiquen als actius en tres tipus: capital físic -financers i pròpiament físics, com en el cas de l'habitatge-, capital humà -treball, salut i educació- i capital social -xarxes socials-. Aquests actius són generats per tres principals fonts: l'estat, el mercat i la comunitat; aquestes conformen la trucada «estructura d'oportunitats». D'aquesta manera, els factors interns i externs, són considerats recursos actius o capitals per a les persones, famílies o comunitats, en la mesura que en ser mobilitzats permeten enfrontar i superar una situació difícil.

Les estructures d'oportunitats són enteses, a partir d'aquests autors, com, «probabilitats d'accés a béns, a serveis o a l'acompliment d'activitats». Aquestes oportunitats incideixen en el benestar de les llars, ja sigui perquè permeten o faciliten als membres de la llar l'ús dels seus propis recursos o perquè els proveeixen recursos nous (Kaztman, 1999). D'aquesta forma, les estructures d'oportunitats podrien ser considerades un tipus més de recurs actiu o capital amb el qual potencialment podrien explicar les famílies per enfrontar les diferents adversitats. En rigor, segons Katzman (1999), els recursos es converteixen en actius en la mesura que permeten l'aprofitament de les oportunitats que ofereix el mitjà a través del mercat, l'estat $\mathrm{o}$ la societat.

Per tant, per a l'anàlisi dels recursos de les llars, a l'efecte d'avaluar la situació de les llars, s'ha de parar esment, simultàniament, a la disponibilitat de recursos i a l'estructura d'oportunitats a la qual ells estan exposats, això és, s'ha de vincular l'anàlisi micro de les llars amb l'anàlisi macro que permet fer el seguiment de les transformacions, en l'estructura d'oportunitats. De res serveix posar només la mirada sobre el que les llars tenen i poden fer, si no 
s'observen les estructures d'oportunitats a les quals les famílies realment poden accedir i aprofitar.

$\mathrm{Al}$ seu torn, cal ressaltar que les estructures d'oportunitats es modifiquen constantment, per la qual cosa les hi ha de considerar una variable i no una constant. Ara bé, que els recursos actius o capitals estiguin presents o no, disponibles i a l'abast de la població i de les llars, i que a més siguin percebuts com a tals, depèn de les estratègies que utilitzin aquests per aconseguir aquests objectius. D'altra banda, no només és necessari que estiguin presents per enfrontar una situació d'adversitat, sinó també que participin d'un joc dinàmic en el qual els recursos actius disponibles es relacionin i combinin a través d'estratègies que implementin els subjectes per fer front a aquestes situacions.

D'aquesta manera pot observar-se que durant el procés de resiliència el subjecte participa activament del joc dinàmic que es dóna entre processos deteriorants i processos protectors. Per tant, que el subjecte estiga resilient o no, enfront d'una determinada situació, dependria dels recursos actius disponibles en un determinat moment i lloc -els quals sens dubte poden variar- i de les estratègies que aquest implemente per enfrontar i superar les circumstàncies d'adversitat. En determinats moments, disposarà d'alguns recursos i d'uns altres no i les estratègies que empri per combinar-los segurament seran diferents a cada moment i davant cada situació particular. Per això és important conèixer les situacions de vida difícils particulars de la població a estudiar i tots els recursos actius disponibles que s'articulen davant l'enfrontament d'aquesta situació.

\section{Resiliència i Capital Social}

L'acció de les persones es troba inserida en un entramat de xarxes de relacions socials que li proporcionen accés -o li impedeixen accedir- a determinats recursos i influeixen en les seves actituds, comportaments i cognicions. Com ja hem apuntat anteriorment, l'exclusió social presenta un caràcter multi dimensional que inclou privació, principalment, de drets econòmics, socials i/o polítics. A més, en el cas de les persones vulnerables o en situació d'exclusió, la seva posició en aquest entramat relacional és de franca feblesa, això és, manquen dels vincles necessaris per poder accedir a recursos socials, polítics, econòmics i culturals que sí estan a la disposició de les persones plenament incorporades. El capital social, a diferència del físic i financer i de l'humà, és depenent de la cobertura territorial i social de les xarxes que ho sustenten i dels

sistemes normatius que regulen aquestes xarxes. És a dir, quan els individus s'allunyen d'aquells altres amb els qui mantenien un vincle, el capital social tendeix a reduir-se.

Cal destacar que la família i la ciutat o barri de residència, és a dir, els nuclis 
més propers de l'individu, són les fonts essencials de capital social. Per tant, la modificació dels mateixos es tradueix en una variació del capital social d'una societat, tant quant a la seva quantitat, com a la seva qualitat i distribució. En aquest sentit l'accés a les estructures d'oportunitats dependrà de les habilitats relacionals de les persones, enteses com la capacitat d'establir relacions i vincles amb altres persones, que incrementen les possibilitats d'obtenció de recursos.

Per la seva banda, en una societat orientada a la qualitat de vida ja no té sentit oferir serveis i encaixar les necessitats en la cartera de serveis públics. Cal redefinir les pròpies necessitats i oferir respostes que incorporin la perspectiva relacional. Això implica que els problemes socials s'interpreten a partir d'una xarxa de relacions sobre les quals s'ha d'intervenir per identificar la solució més apropiada.

La intervenció social no pot limitar-se a identificar la causa del problema i intervenir sobre el mateix de forma aïllada. «El treball de xarxes tracta de fer això redefinint el problema com una situació generada per una xarxa problemàtica de relacions. I la solució ha de buscar-se en les accions sobre relacions, no en un altre lloc». La idea de «vulnerabilitat relacional», entesa com a absència o feblesa dels vincles d'inserció comunitària present en la perspectiva relacional implica que l'acció s'ha de focalitzar a l'entorn de vida de les persones, generant xarxes relacionals i de suport social que actuïn com a font d'oportunitats vital. ${ }^{1}$

D'aquí la importància de tenir en compte, en l'anàlisi de la resiliència, la presència i la interacció i joc dinàmic entre recursos actius enfront de contextos de risc.

\section{Consideracions finals: raons per incorporar l'enfocament de resiliència}

Si considerem la resiliència -que engloba a un conjunt de variables-, com una capacitat que involucra la dinamització dels recursos actius presents en els diferents moments del cicle vital de les persones i comunitats, per afrontar contextos de vida difícils o situacions d'exclusió social. la resiliència pot ser una eina vàlida i necessària per enfrontar situacions de desavantatge, adverses, difícils, però perquè aquesta capacitat pot desenvolupar-se cal considerar les possibilitats d'accés a les estructures d'oportunitats, com a variable fonamental per acumular i mobilitzar recursos actius. Per la seva banda, l'ésser humà pot ser resilient quan supera una situació angoixant gràcies als vincles donats per

1. Document elaborat per Navarro Pedreño, Silvia per al Seminari «La perspectiva relacional de intervención». DE CÓMO ROBINSON CRUSOE (RE)DESCUBRIÓ A VIERNES: reflexiones sobre la perspectiva relacional de la intervención social hoy. 2011 
les xarxes socials, pels agents socialitzants, i sobretot, per les característiques de la personalitat o factors protectors interns.

Els membres del Grup d'Alt Nivell de Persones Eminents sobre l'Agenda de Desenvolupament Post-2015, en el seu informe «Una nova Aliança Mundial: Eradicar la pobresa i transformar les economies a través del desenvolupament sostenible (2013)», han acordat que «la pobresa té diverses manifestacions, inclosa la falta d'ingressos i recursos productius suficients per garantir mitjans de subsistència sostenibles, gana i desnutrició, mala salut, falta d'accés o accés limitat a l'educació i a altres serveis bàsics, augment de la morbiditat i mortalitat per malaltia, falta d'habitatge i allotjament inadequat, ambients insegurs, i discriminació i exclusió social. També es caracteritza per una falta de participació en la presa de decisions i en la vida civil, social i cultural».

Segons aquest Grup esmentat, per abordar aquests desafiaments, una de les metes se centra en la capacitat de resistència o resiliència. Resiliència significa -per a ells- que els individus estiguin llests per resistir, siguin capaços d'adaptar-se, quan es tracta de commocions relacionades amb la salut, l'economia o el clima, i capaços de recuperar-se ràpidament. La resiliència permet a les persones sortir dels marges de la supervivència per fer inversions a llarg termini en el seu propi futur mitjançant una educació, millor salut, augment dels seus estalvis i protecció per als seus actius físics més valuosos, com a llar, propietats i mitjans de subsistència.

Treballar des de l'òptica de la resiliència suposa treballar sobre aquests problemes, però també, i de manera fonamental, treballar en prevenció, així com treballar al més aviat possible amb poblacions en risc d'exclusió social, i el més primerenc possible quant al moment del cicle vital.

La resiliència permet una nova epistemologia del desenvolupament humà, en tant emfatitza el seu potencial. Un enfocament en resiliència permet que la promoció de la qualitat de vida sigui també una labor col-lectiva. Com a societat i com a individus els desafiaments són cada dia més complexos i requereixen solucions més compromeses i integrals.

\section{Referències}

Arriagada, I. (2005). Dimensiones de la pobreza y políticas desde una perspectiva de género. Revista de la CEPAL, 85, 101-113.

Becoña, E. (2006). Resiliencia: definición, características y utilidad del concepto. Revista de Psicopatología y Psicología Clínica, 11(3), 125-146.

Blaikie, P.; Cannon, T.; David, I. i Wisner, B. (1996). Vulnerabilidad: El entorno social, político y económico de los desastres. Red de Estudios Sociales en Prevención de Desastres en América Latina. IT. Perú. 
Bonanno, G. (2004). Loss, Trauma, and Human Resilience. Have we underestimated the human capacity to thrive after extremely aversive events? American Psychologist, 59(1), 20-28.

Bronfenbrenner, U. (1979). The Ecology of Human Development: Experiments by Nature and Design. Cambridge, Gran Bretaña: Harvard University Press.

Carver, C. S. (1998). Resilience and thriving: issues, models and linkages. Journal of Social Issues 54, (2), 245-266.

Chambers, R. (1989). Vulnerability, coping and policy, IDS Bulletin $N^{o} 20$.

Com (2003/773). Informe conjunto sobre la inclusión social en el que se resumen los resultados del examen de los planes nacionales de acción en favor de la inclusión social (2003-2005), Comisión Europea, Bruselas.

Cyrulnik, B. (2002). Los patitos feos. La resiliencia: una infancia infeliz no determina la vida. Barcelona: Gedisa.

Federación Internacional de la Cruz Roja (2012). El camino hacia la resiliencia: Tender puentes entre el socorro y el desarrollo para un futuro más sostenible. Recuperado de <https://www.ifrc.org/PageFiles/96178/1224500Road\%20to\%20resilience_Sp_Web.pdf $>$.

Gauto, G. (2008). Resiliencia para enfrentar los contextos de desigualdad y pobreza vinculados a los procesos salud-enfermedad y hábitat desde la mirada de los derechos humanos de tercera generación y la vulnerabilidad social. III Congreso de la Asociación Latinoamericana de la Población, (pp. 1-15). Córdoba, Argentina.

Godoy Izquierdo, D. i Godoy, J. (2002). La personalidad resistente: una revisión de la conceptualización e investigación sobre la dureza. Clínica y Salud, 13, 135-162.

Madariaga, C. i Sierra, O. (2000). Redes sociales y pobreza. Psicología desde el Caribe, 5, 127-156.

Grotberg, Edith (1996). Fortaleciendo el espíritu humano. (Trad. Néstor Suárez Ojeda). La Haya: Fundación Bernard van Leer.

Grotberg, Edith (1997): La resiliencia en acción, trabajo presentado en el Seminario Internacional sobre Aplicación del Concepto de Resiliencia en Proyectos Sociales. Universidad Nacional de Lanús, Fundación Van Leer.

IVIE (2014). Pobreza en un período de crisis económica. Cuadernos de Capital Humano, 145.

Kaztman, R. (2001). Seducidos y abandonados: el aislamiento social de los pobres urbanos, Revista de la CEPAL, 75 (LC/G.2150-P), Santiago de Chile, diciembre.

Kaztman, R. (2000). Notas sobre la medición de la vulnerabilidad social, $5^{\circ}$ Taller Regional. La medición de la pobreza: métodos y aplicaciones (continuación) (LC/R.2026), Santiago de Chile, Banco Interamericano de 
Desarrollo (BID)-Banco Mundial-Comisión Económica para América Latina y el Caribe (CEPAL)-Instituto Brasilero de Defensa del Consumidor (IDEC), Aguascalientes, 6 al 8 de junio.

Kaztman, R. (Coord.) (1999). Activos y Estructuras de oportunidades. Estudio sobre las raíces de la vulnerabilidad social en Uruguay. LC/MVD/R. 180. UN/CEPAL. Oficina de Montevideo. Uruguay.

Kaztman, Rubén i Filgueira, Carlos (1999). Capítulo I Notas sobre el marco conceptual. En Kaztman, Rubén (Coord.): Activos y Estructuras de oportunidades. Estudio sobre las raíces de la vulnerabilidad social en Uruguay. LC/MVD/R. 180.UN/CEPAL. Oficina de Montevideo. Uruguay, pp. 19-36.

Manciaux, M.; Vanistendael, S.; Lecomte, J. i Cyrulnik, B. (2001). La resiliencia: estado de la cuestión. En: Manciaux, M. (comp.): La resiliencia: resistir y rehacerse. Madrid: Gedisa, 2003.

Manciaux, M. (2003). La resiliencia: resistir y rehacerse. España: Gedisa.

Melillo, A. (2004). Prefacio. En A. Melillo y N. Suárez Ojeda (comps.): Resiliencia. Descubriendo las propias fortalezas. $1^{\mathrm{a}} \mathrm{ed}, 3^{\mathrm{a}}$ reimp., Buenos Aires, Argentina, Editorial Paidós SAICF. pp. 15-18.

Melillo, A.; Estamatti, M. i Cuestas, A. (2004). Algunos fundamentos psicológicos del concepto de resiliencia. Capítulo 4. En A. Melillo y N. Suárez Ojeda (comps.): Resiliencia. Descubriendo las propias fortalezas. $1^{\mathrm{a}}$ ed, $3^{\mathrm{a}}$ reimp., Buenos Aires, Argentina: Editorial Paidós SAICF. pp. 83-102.

Naciones Unidas (2013). Una nueva Alianza Mundial: Erradicar la pobreza y transformar las economías a través del desarrollo sostenible. United Nations Publications, 300 E 42nd Street, New York, NY 10017.

O'Leary, V. E. (1998). Strength in the face of adversity: individual and social thriving. Journal of Social Issues, 54(2), 425-445.

Rojas, M. (2002). Aprendizaje transformacional en la familia y la educación. Revista Venezolana de Análisis de la Coyuntura, 8(1), 189-200.

Rojas, M. C. (2004). Lineamientos Teóricos para la estimación holística de la vulnerabilidad y el riesgo de la vivienda en la salud humana. Una revisión necesaria para la gestión de la vivienda saludable. Cuaderno Urbano $N^{\circ}$ 4. Espacio, Cultura, Sociedad. Publicación EUDENE Editorial de la Universidad Nacional del Nordeste, Facultad de Arquitectura y Urbanismo. Edición Forourbano. Instituto de Planeamiento Urbano y Regional (IPUR) Instituto de Investigación y Desarrollo en Vivienda (IIDVI). ISSN: 1666-6186. pp 147-174.

Rojas Marcos, L. (2010). Superar la adversidad: el poder de la resiliencia. Barcelona: Ed. Espasa.

Rojas Marcos, L. (2014). Discurso de aceptación del grado de doctor honoris causa otorgado por la Universitad del País Vasco/Euskal Herriko Unibertsitatea Bilbao, 9 de Mayo de 2014. 
Rutter, M. (1987). Psychosocial Resilience and Protective Mechanisms. American Journal of Orthopsychiatry, 57(3).

Rutter, M. (1993). Resilience: Some Conceptual Considerations. Journal of Adolescent Health, 14(8).

Seccombe, K. (2002). Beating the Odds versus Changing the Odds: poverty, resilience, and family policy. Journal of Marriage and Family, 64, 384-394.

Seligman, M. E. P. i Csikszentmihalyi, M. (2000). Positive Psychology: An Introduction. American Psychologist, 55, 5-14.

Silver, H. (1994). Exclusión social y solidaridad social. Tres paradigmas, en Revista Internacional del Trabajo, 113(5-6), OIT, Ginebra.

Silver, H. (2007). The process of social exclusion: The dynamics of an evolving concept. Chronic Poverty Research Centre, CPRC Working Paper 95, Brown University, United Kingdom.

Suárez Ojeda, E. N. (1993). Resiliencia, o capacidad de sobreponerse a la adversidad. Medicina y sociedad, 16(3). Buenos Aires, Argentina.

Suarez Ojeda, E. N. (2004). Perfil del niño resiliente. En E. N. Suarez Ojeda, M. Munist i D. Rodríguez (comps.): Seminario Internacional sobre aplicación del concepto de resiliencia en proyectos sociales. Departamento de Salud Comunitaria, Centro Internacional de Información y Estudio de la Resiliencia (CIER), Universidad Nacional de Lanús (UNLa), Fundación Bernard Van Leer. $2^{\text {a }}$ ed. Buenos Aires, Argentina: Ediciones de la UNLa, pp. 23-31.

Suárez Ojeda, E. N. et al. (2007). Trabajo comunitario y resiliencia social. En M. Munist et al. (comp.): Adolescencia y resiliencia. Buenos Aires: Paidós.

Vanistendael, S. (1994). La resiliencia: Un concepto largo tiempo ignorado. BICE. Ginebra, Suiza.

Vanistendael, S. (1995). Cómo crecer superando los percances. Cuaderno BICE. Ginebra, Suiza. 